\title{
Firm characteristics and capital structure of cement firms in Nigeria
}

\author{
Kamal Tasiu Abdullahi ${ }^{1 *}$, Suleiman Umar Suleiman ${ }^{2}$ \\ ${ }^{1}$ Department of International Economics, Marmara University, Istanbul, Turkey \\ ${ }^{2}$ Department of Accounting, Ahmadu Bello University, Zaria Kaduna, Nigeria
}

\section{Keywords \\ Firms \\ Capital structure \\ Cenmentt firms \\ Nigeria}

Received: 7 November 2019

Accepted: 10 January 2020

Published: 8 April 2020

\begin{abstract}
This study aims to determine the impact of benefit on capital structure of recorded cement firms in Nigeria and descriptive and ex-post facto design to establish the firm's distinctiveness of capital structure among Nigeria's cement firms. Also, correlation and regression analysis will be used for this research. The research adopted descriptive and ex-post-facto design to establish the firms' capital structure characteristics among the cement firms in Nigeria. The ex-post facto design is used to establish the impact between the leverage (dependent variable) and Profitability, Firm size, Tangibility of assets, Firm growth, and Liquidity. The result produces proof to accept the null hypothesis, in hypothesis one, which states that firm profitability has no significant impact on the capital structure of cement firms in Nigeria. By implication, the alternative hypothesis, which states vice versa to the above, should be rejected. Capital structure is one of the successful apparatuses of administration to oversee the fetches of capital. An ideal capital structure is achieved when the capital cost is not much. Even though a few ponders have been done on the determinants of capital structure, imperative questions remain on what are the determinants of the capital structure of firms in different sector.
\end{abstract}

\section{INTRODUCTION}

A capital structure decision make by firms have an impact on the net cost or value of a certain firm. To finance their assets firms combine both debt and equity. A good judgment can increase shareholders' wealth while a poor decision may diminish the net esteem of the firm. According to Kamau (2010) capital structure shows the amount of liability instruments and financial state of a firm. Firms utilize debt and equity to back their deals or boost their showcase esteem and this value and obligation can be within the shape of bank advances, rent financing, bond and numerous other alternatives (Booth, Aivazian, Demirguc-Kunt, \& Maksmivoc, 2001; Shin \& Seo, 2017).

A few variables influence a firm's capital structure and it is cleared out for the firm to decide which figure is ideal. A firm can use a particular factor or several mix of financial to achieve optimality. Optimal mixing of finance gives a firm two advantages which are maximization of the value of the firm and minimizing its cost of capital, though this is not a science and there is a need for a firm to figure out which of the capital structure will make it reach its optimality.

The 'irrelevance theory' of Modigliani and Miller (1958) argue that under certain assumptions due to arbitrage structure that exists in the capital market the value of a firm is independent. Furthermore, to neutralize capital structure decision, both the investor and the firm can have a loan at the same interest rate. The unlikely presumptions of this hypothesis gave birth to pecking order theory and tradeoff theory. In the tradeoff theory optimal leverage of a firm is based on three factors which are agency costs, costs of financial distress, and taxes which give a firm a chance to consider its costs and benefits related with debt capital in bringing its capital structure close to the ideal level. According to pecking order theory, firm managers are more knowledgeable than investors; therefore, these managers prefer to finance new projects first before issuing debt or new eq-

${ }^{*}$ corresponding author: Kamal Tasiu Abdullahi

†email: kmlts256@gmail.com 
uity (Myers, 1984; Onegi, Eser, \& Korkmaz, 2019).

Cement firms in Nigeria came into being almost before independence (Chode, 2003; Mugenda \& Mugenda, 1999). In Nigeria, there are many cement firms which include Wapco, Dangote, Benue Cement, Ashaka Cement and Sokoto Cement with an estimated market size of N361 billion (US\$2.4billion) and production of 13.4 million tons (Donaldson \& Stone, 1984). As reported by Kuria (2010), these firms have been contributing immensely to the economic growth of Nigeria.

Theoretically, capital structure plays a vital role for every firm, but for this to happen, there should be a mix of both equity and debt in an optimal way to make the most of the firm's worth and reduce the rate of capital. However, realistically, perfectly optimal capital structure is almost impossible to determine because of some conflicting variables (Baxter, 1967). In this study potential characteristics of firm's that determines such optimal capital structure will be analyzed with a focus on Dangote cement (DANGCEM), Lafarge cement WAPCO Nigeria (LCW), Ashaka Cement (ASC), Cement Company of Northern Nigeria (CCNN).

\section{LITERATURE REVIEW}

Capital structure can be seen as a way through which a firm combines hybrid securities, debt or equity to finance it assets (Shyam-Sunder \& Myers, 1999). Firms utilize capital structure to grow their operation and utilize diverse sources of back which can be vendor financing, debt, capital or equity (Kurniawan, 2018; Rajan \& Zingales, 1995). Ferri (2005) used different variables namely, industry type, operating leverage, business risk and firm size to carry out a study in the United States between 1960-1969 using 89 firms in determining the effectiveness of capital. The study indicates th leverage. In at firm size and operating leverage are significantly related to leverage which in turn affects a firm capital structure.

Saunders, Lewis, and Thornhill (2009) carried out a study on 66 different firms from 1977 to 1980 utilizing seven diverse factors which include t-test, multiple regression model and correlation to determine the financial structure of firms. The research shows that the size of a firm does not affect its financial leverage. In According to Titman and Wessels (1988) study on figure investigation strategy for assessing the affect of inconspicuous traits on the choice of corporate debt proportion utilizing the information from the 469 UK firms for the period of nine years from 1974-82, the study finds that debt levels are contrarily related to uniqueness of a firm's line of commerce. The findings also show that operation costs may be a critical determinant of capital structure alternative in line with firm size. According to Odinga (2003) adopted backward multiple regression model to categorize important factors distressing capital structure by taking into consideration leverage ratio as dependent variable. The autonomous factors were growth, size, business risk, operating leverage, dividend payout ratio, debt coverage, profitability, and cash flow coverage. She concluded that whereas planning capital structure of a firm, the companies allow major importance to the dividend payout ratio, growth, size, business risk, profitability and tax shield.

Bevan and Danbolt (2001) analyzed the dynamics in the capital structure of UK companies from 1991 to 1997. They observed significant changes in the relative importance of the various debt elements over time, as well as changes within the relationship between equipping and the level of development, tangibility, company size, and profitability. The findings of the study revealed that UK way of handling credit has changed drastically all through the 1990s, with huge companies utilizing less bank fund and banks progressively loaning to littler firms. At the same time, bank debt shows up to have ended up more closely related to corporate benefit and collateral values.

DeAngelo and Masulis (1980) looked at the affect of benefit, asset tangibility, growth and size on capital structure choices of Turkish mechanical firms to that corporate administration and equity ownership structure may impact the relationship between firm's characteristics and debt ratios. By using regression analysis, Gonenc found that some factors such as stock market activities, government, and equity ownership by managers determine the capital structure of the firms in Turkey just like the ones in developed and developing countries.

Drobetz and Fix (2003) in their research on capital found that logical factors like inflation rates, capital markets, and GDP growth alter the way the debt ratios are affected by some factors in the developing countries. In Ukraine for example, tangibility factor was highly important in their regressions and established the assumptions of the significant theories tested for non-transition economies. They assumed that excessive assets and environmental factors can cover production capacities and excessive tangible assets in case of a transition economy.

Ozkan (2001) used descriptive research design of 86 different manufacturing companies that are listed in the Nigerian Stock Exchange to examine the factors that determine capital structure in Nigeria. In their findings, the result showed that there is a negative relationship between capital structure and firm size and tax and positive relationship between 
capital structure and tangibility of assets, profitability, and growth.

Turere (2012) studied and investigated how impactful capital structure is on the performance of firms in Nigeria by taking into account short and long-term debt of financial performance of some selected firms using a panel data and least square. The findings revealed that there is a negative correlation between capital structure and financial performance in the short-term and in the long term the relationship is positive.

\section{RESEARCH METHODOLOGY}

The research adopted descriptive and ex-post facto design to establish the characteristics firms capital structure among the cement firms in Nigeria Namely Dangote Cement (DANGCEM), Ashaka Xement (ASC), Cement company of Northern Nigeria (CCNN) and Lafarge Cement WAPCO Nigeria (LCW). To conduct this study, a descriptive research was used because of it effectiveness to describe how lever- age is related to any one of the independent variables, that is;, Firm size, , Firm growth, Profitability, Liquidity, Tangibility of assets. On the other hand, the ex-post facto design is used to establish impact between the leverage (dependent variable) and Profitability, Firm size, Tangibility of assets, Firm growth, and Liquidity.

\section{DATA ANALYSIS AND RESULTS}

This part presents the data used in to carry out the study upon which the analysis is based. The data collected are in respect of capital structure as leverage and firm characteristics as profitability, size of firm, tangibility, growth and liquidity of listed cement firms in Nigeria. The Data for the study were gathered from published financial statements available at NSE and CSPR as well as the company head offices and websites. This was at that point utilized to compute the different proportions which constituted factor for the research. The below table presents the data as follows:

TABLE 1. Data presentation

\begin{tabular}{llllllll}
\hline \hline YEAR & FIRM ID & LEV & PF & SF & AT & FG & LQ \\
\hline 2009 & ASC & - & - & - & - & - & - \\
2010 & ASC & 0.42592 & 0.15537778 & 4.31764554 & 0.6649244 & 17.256977 & 1.222784 \\
2011 & ASC & 0.445712 & 0.12781189 & 4.35903823 & 0.5350522 & 9.09099 & 1.483473 \\
2012 & ASC & 0.264553 & 0.06738953 & 4.33897415 & 0.7169996 & -4.72835 & 1.98221 \\
2013 & ASC & 0.30057 & 0.04218145 & 4.33633964 & 0.7227059 & -0.608463 & 2.417561 \\
2014 & ASC & 0.283324 & 0.07339988 & 4.32496115 & 0.6967117 & -2.654616 & 2.668922 \\
2015 & ASC & 0.246675 & 0.04559793 & 4.24089854 & 0.7159685 & -21.35637 & 2.702542 \\
2009 & DANGCEM & - & - & - & - & - & - \\
2010 & DANGCEM & 0.126827 & 0.25722814 & 5.30656655 & 0.7099866 & 6.390597 & 2.376524 \\
2011 & DANGCEM & 0.143661 & 0.2212631 & 5.37275556 & 0.8473159 & 14.136023 & 1.186384 \\
2012 & DANGCEM & 0.126719 & 0.20135794 & 5.47487744 & 0.749266 & 20.954317 & 2.032819 \\
2013 & DANGCEM & 0.304413 & 0.243413 & 5.57001844 & 0.8333465 & 19.673476 & 0.906929 \\
2014 & DANGCEM & 0.337226 & 0.2211234 & 5.56999856 & 0.8776625 & -0.004575 & 0.572723 \\
2015 & DANGCEM & 0.334375 & 0.1961519 & 5.59018957 & 1.7002534 & 4.5427334 & 0.800834 \\
2009 & WAPCO & - & - & - & - & - & - \\
2010 & WAPCO & 0.592472 & 0.06949637 & 4.64188045 & 0.8503558 & -3.987135 & 0.310455 \\
2011 & WAPCO & 0.632868 & 0.07639353 & 4.79386718 & 0.8354032 & 29.528539 & 0.841145 \\
2012 & WAPCO & 0.550112 & 0.14457482 & 4.94430997 & 0.8430526 & 29.277553 & 0.76277 \\
2013 & WAPCO & 0.570336 & 0.152272 & 4.97957569 & 0.8419937 & -8.459046 & 0.720657 \\
2014 & WAPCO & 0.088573 & 0.0941486 & 5.02468266 & 0.9263766 & 9.8754818 & 0.69263 \\
2015 & WAPCO & 0.075248 & 0.0810624 & 5.05913914 & 0.9135053 & 7.6273257 & 0.659824 \\
2009 & CCNN & - & - & - & - & - & - \\
2010 & CCNN & 0.547897 & 0.19251935 & 4.04848065 & 0.506949 & -6.144352 & 1.207676 \\
2011 & CCNN & 0.442836 & 0.27758772 & 4.14348321 & 0.4638396 & 19.647862 & 1.790383 \\
2012 & CCNN & 0.463629 & 0.12673782 & 4.17972496 & 0.4566072 & 8.0060822 & 1.520134 \\
2013 & CCNN & 0.449794 & 0.1397928 & 4.18500356 & 0.4714438 & 1.2082816 & 1.940502 \\
2014 & CCNN & 0.401394 & 0.15690748 & 4.17952367 & 0.5306717 & -1.269925 & 2.118135 \\
2015 & CCNN & 0.408375 & 0.09034177 & 4.11517767 & 0.5903418 & -15.96993 & 1.666825 \\
\hline \hline & & & & & & &
\end{tabular}




\section{Descriptive Statistics}

This segment analyzes descriptive statistics of both dependent and independent variables.

From table above, the average leverage ratio of firm is about $35 \%$. The maximum level of the leverage is about $63 \%$ while the minimum is $7 \%$. The table also indicates that only firm growth of the firm has the uppermost standard deviation, it is expected that these exogenous variables will give fewer to the endogenous changes under this research. The profitability in the firms stood at an average of $14 \%$ under the period of the study whereas the potential for growth is about $5.50 \%$.

TABLE 2. Summary of descriptive statistics (2010-2015)

\begin{tabular}{llllllllll}
\hline \hline & Obs. & Mean & Std. dev & Min. & Max. & Skewness & Kurtosis & VIF & Tolerance \\
\hline LEV & 24 & 0.3568 & 0.1656 & 0.0752 & 0.6328 & -0.1615 & 2.014 & - & - \\
PF & 24 & 0.1439 & 0.0698 & 0.0421 & 0.2775 & 0.2797 & 1.9444 & 1.59 & 0.6286 \\
FS & 24 & 4.7123 & 0.5464 & 4.0484 & 5.5901 & 0.4002 & 1.6165 & 3.33 & 0.3006 \\
AT & 24 & 0.75 & 0.2525 & 0.4566 & 1.7002 & 2.1074 & 9.4379 & 2.63 & 0.3809 \\
FG & 24 & 5.5013 & 13.097 & -21.35 & 29.528 & 0.045 & 2.5174 & 1.39 & 0.7168 \\
LQ & 24 & 1.441 & 0.7181 & 0.3104 & 2.7025 & 0.2532 & 1.8309 & 1.42 & 0.7028 \\
\hline \hline
\end{tabular}

Sources: STATA 13 Regression Results Using Secondary Data

On the average, growth of firm stood at $13 \%$ during the period of the study, this can be justified by the means of the profitability of the firms. The result indicates over the sixyear period, the cement firms had a mean leverage of 0.35 , profitability of 0.14 , firm size of 4.71 , asset tangibility of 0.75 , firm growth of 5.50, and liquidity of 1.44 . The standard deviation values were all less than one which indicates that there were no significant variations except for growth in the responses.

The variance inflation and tolerance factor are two trial of multicolinearity between the variables involved in the study. From the above table, the variance Inflation Factor (VIF) is relatively small, not up-to ten (10) and the tolerance which is the inverse of the VIF is not up to one (1) showing further that there is no multicolinearity among the indepen- dent variables that are used in the study.

The skewness values show that they are all close to 0 and 1 with the exception of Asset tangibility which indicate a little bit higher value than it used to be which makes the date to be distributed tolerably extreme and this shows that the Kurtosis and regression results are valid which were greater than 1 and the Asset tangibility with a higher value.

\section{Correlation Analysis}

This segment presents correlation analysis summary for the dependent variables and explanatory variables for the study. The correlation analysis shows the degree of the correlation between two factors. The sample consists of $24 \mathrm{ob}-$ servations derived from yearly reports of four (4) listed cement firms in Nigeria for the period of 2010-2015.

TABLE 3. Correlation results (observation = 24)@(0.05) significance

\begin{tabular}{lllllll}
\hline \hline & LEV & PF & FS & AT & FG & LQ \\
\hline LEV & 1 & & & & & \\
PF & -0.0839 & 1 & & & & \\
& 0.6966 & & & & & \\
FS & $-0.4163^{*}$ & $0.4492^{*}$ & 1 & & & \\
& 0.043 & 0.0277 & & & & \\
AT & -0.2152 & 0.0394 & $0.6998^{*}$ & 1 & & \\
& 0.3125 & 0.8548 & 0.0001 & & & \\
FG & 0.0291 & $0.3937^{*}$ & 0.39 & 0.1018 & & \\
& 0.8925 & 0.057 & 0.0596 & 0.636 & & \\
LQ & -0.2913 & -0.1341 & $-0.4612^{*}$ & $-0.4587^{*}$ & -0.326 & 1 \\
& 0.1673 & 0.532 & 0.0233 & 0.0242 & 0.1196 & \\
\hline \hline
\end{tabular}

** Correlation is significant at the level of $5 \%{ }^{* *}$ Source: STATA 13 Version Correlation Result 
The tables presents the correlation among the variables, as the above table shows that the correlation coefficients of the factors. The table presents a negative association between profitability and leverage from the correlation coefficient of -0.0839 which is statistically insignificant. The relationship between leverage and firm size indicate that there was a negative significant relationship between the two variables of which -0.4163 is important at level $5 \%$ of significance. The result also shows that there is a negative significant connection between asset tangibility and leverage from the correlation coefficient of -0.2152 that is statistically in- significant. There was a positive important relationship between leverage and firm growth in which the correlation coefficient was 0.0291 which was statistically insignificant. Whereas the relationship between leverage and liquidity was examined and the two variables of which - 0.2913 is statistically insignificant.

\section{Regression Analysis}

This analysis was conducted using the leverage as the dependent the independent variables were, firm growth, profitability, firm size, asset tangibility and liquidity. The results are tabulated below:

TABLE 4. Model Summary and regression results

\begin{tabular}{llll}
\hline \hline Variable & Coefficient & $\boldsymbol{t}$-Value & $\boldsymbol{p}$-value \\
\hline PF & 0.4799 & 0.86 & 0.403 \\
FS & -0.2764 & -4.33 & 0 \\
AT & 0.0876 & 1.11 & 0.283 \\
FG & 0.0012 & 0.43 & 0.673 \\
LQ & -0.1363 & -3.54 & 0.002 \\
Cons & 1.7143 & 9.32 & 0 \\
F-Stat. & & & 18.79 \\
F-Sig. & & & 0 \\
$R$ & & & 0.7134 \\
$R^{2}$ & & & 0.5089 \\
Adj. $R^{2}$ & & & 0.3725 \\
\hline \hline
\end{tabular}

Sources: STATA 13 version output of data inputted by the researchers

The table above captures the summary of the regression from the model, the $F$-values indicates the fitness of the model used in the research. The $F$-statistics $=18.79$ shows that the model is statistically significant at 0.0000 level of significance indicating the applicability of the overall model. Based on the above statistically significant result after F-statistic, the R2 which showed 0.5089 equivalents to $50.89 \%$ is the coefficient of determination which means that $50.89 \%$ of the variations in the dependent variable (LEV) are caused by the independent variables (PF, FS, AT, FG, LQ) jointly while the remaining $49.11 \%$ is caused by other factors other than the ones used in the study. The adjusted $R^{2} 0.3725$ equivalents to $37.25 \%$ indicates after adjusting for error the coefficient of determination, R2indicates that the independent variables can still give details of the dependent variable by $49.11 \%$. From the Table 4 above, Robust OLS regression was used based on the outcome of the Langrangian multiplier test result which turns out to be insignificant.

From the table, profitability is irrelevant with $p$-value of
0.403 . The standardized coefficient 0.479 signifies that profitability is positively related to capital structure of cement firms in Nigeria. The result produces an proof to accept the null hypothesis, in the hypothesis one which states that firm profitability has no significant impact on capital structure of cement firms in Nigeria. By implication, the alternative hypothesis which states vice versa to the above should be rejected. On the other hand, the Firm Size (FS) is significant at $1 \%$ with $p$-value of 0.000 .The standardized coefficient -0.2764 signifies that firm size is negatively and strongly significant on capital structure (LEV) of the study. The result produces an evidence to fail to accept the null hypothesis in the hypothesis two which states that firm size has no significant relationship on capital structure of cement firms in Nigeria. As well as Asset Tangibility (AT) and Firm Growth (FG) are both insignificant with $p$-values of 0.283 and 0.673 respectively. The standardized coefficient 0.0876 and 0.0012 respectively signifies and implies that they are both positively related on capital structure (LEV) of cement firms in Nigeria. In which the result produces ev- 
idence which accept the null hypothesis, in hypothesis three and four of the study which states that; Asset tangibility has no significant relationship on capital structure and firm growth has no significant relationship on capital structure of cement firms in Nigeria, by implication the alternative hypothesis should be rejected.

Likewise, liquidity (LQ) is significant at $1 \%$ with $p$-value of 0.002 , thestandardized coefficient -0.136 implies that liquidity is negatively and strongly significant on capital structure of cement firms in Nigeria.

In this regard the finding from the above study is also in conformity of Odinga (2003) but is in disagreement with the finding of Turere (2012) and Ferri (2005).

\section{DISCUSSION OF POST ESTIMATION TESTS}

The robustness was conducted in this study to improve the validity of the statistical results. Different test has been conducted such as multicolinearity test, shapirowilk test for normality, Hausman fixed random with chi2 value of 2.31 with $p$-value of 0.8052 , while Breusch and pagan Langrangian multiplier test for random effects in which it implies a problem of Hetrokedasticity because the Hettest reveals a chi 2 value of 0.44 with $p$-value of 0.5048 and that the $p$-value Breusch and pagan Langrangian multiplier test for random effect is 1.000 which is $100 \%$ insignificant.

Moreover, the robustness test reduced the problem of Hetrokedasticity and which reveals that there is a positive relationship between profitability, Asset tangibility, firm growth and leverage measures, with p-value of $0.403,0.283$ and 0.673 respectively. The result implies that the null hypothesis is to be accepted in which the alternative hypothesis as above is to be rejected.

On the other hand, Firm size and liquidity tends to be significant at $1 \%$ and $5 \%$ respectively with p-values of 0.000 and 0.002 respectively; that they are negatively and strongly significant on capital structure of cement firms in Nigeria.

\section{POLICY IMPLICATIONS OF FINDING}

From the view point of firm's characteristics and capital and capital structure, the findings of this study will assist in establishing financial policy, guidelines that will guide against the negative impact of firm characteristics on capital structure of cement firms in Nigeria.

Regarding firm size and liquidity the finding identifies negative and significant impact on capital structure which provides substantial evidence to managers and other stakeholders that any increase in firm size and liquidity leads to decrease in their capital structure i.e. mixture of debt and equity of their holding. To help users make an informed de- cision on the capital structure of the firms, there is need to adequately define such firm characteristics.

The SEC, CBN can as well formulate policies in issuing out guidelines for such scenarios by firms in the capital market which will enhance capital structure.

\section{CONCLUSION}

This paper presents analysis of firm's characteristics and capital structure of Nigerian listed cement firms based on the data available on their annual reports for the period 2010-2015. The effect of five explanatory variables is measured on leverage ratio. We first present some descriptive statistics on our selected variables; the most interesting finding of our descriptive is the average of profitability with $14 \%$ for the firms and multiple regression analysis was applied in the study.

- This study concludes that profitability had a positive impact and is a firm characteristics of capital structure of cement firms in Nigeria and it is the most influential variable in the study, this means that as profitability increases the value of leverage will also increase and vice versa.

- Firm size had a negative impact on capital structure of cement firms in Nigeria, it concludes that as the size of firm increases leverage decreases and vice versa, this means that firm size does not contribute to leverage of the firm.

- Asset tangibility also had a positive impact on capital structure of cement firms in Nigeria which implies that as asset tangibility increases, leverage also increases and vice versa and therefore it contributes positively to the creation of leverage.

- Firm growth had a positive impact on capital structure of cement firms in Nigeriabut with least impact on leverage, but still plays a vital role in increasing the leverage of the firm as it increases.

- Liquidity had a negative impact on capital structure of cement firms in Nigeria, in this case as liquidity increases, leverage decreases and vice versa.

Literature suggests that debt requirements of a firm in one industry differ from the firm in another industry; hence firm's characteristics of capital structure are different across industries (Titman \& Wessels, 1988). The reason for this is because in the environment, business risk varies across the industries. The cement manufacturing industry is unique in many aspects compared to other sectors in Nigeria.

\section{RECOMMENDATIONS}

Some of the factors to consider when making capital structure choice in this regard include profitability, firm growth, 
asset tangibility and liquidity. Chief Finance officers of firms in the cement firms should take into account the industry norms when developing their financial policies.

Capital structure of comparable firms should be considered because it might reflect the unique risks inherent in that industry. The following recommendations were made among others from the conclusion of the study:

- Profitability: Since profitability had a positive impact on leverage, therefore it is recommended that firms should embark and concentrate more on profitability concept so as to gain much of capital structure of the firm and limit themselves from debt financing.

- Firm Size: Marketing managers should encourage and be able to boost marketing strategies, promotions and bonuses in order to gain large market size through sales.

- Asset tangibility: managers should be careful with firm's asset tangibility of to avoid insolvency of firm.

- Firm growth: firms should also concentrate and ensure revaluation of assets and changes in non-current asset in order to avoid wastages and damages.

- Liquidity: It is said to have a negative impact on leverage as well be recommended to overlook the working capital of the firm to ensure survival of the company bearing the competitive condition in the firm and provide control measures against liquidation.

\section{REFERENCES}

Baxter, N. D. (1967). Leverage, risk of ruin and the cost of capital. The Journal of Finance, 22(3), 395-403. doi:https:// doi.org/10.1111/j.1540-6261.1967.tb02975.x

Bevan, A., \& Danbolt, J. (2001). Capital structure and its determinants in the United Kingdom: A de-compositional analysis (Working paper no. 2000-2). University of Glasgow, Glasgow, Scotland.

Booth, L., Aivazian, V., Demirguc-Kunt, A., \& Maksmivoc, V. (2001). Capital structures in developing countries. Journal of Finance, 56(4), 87-130. doi:https://doi.org/10.1111/0022-1082.00320

Chode, P. (2003). Determinants of capital structure of public sector enterprises in Kenya (Unpublished master's thesis). University of Nairobi, Kenya, Nairobi.

DeAngelo, H., \& Masulis, R. W. (1980). Optimal capital structure under corporate and personal taxation. Journal of Financial Economics, 8(1), 3-29. doi:https://doi.org/10.1016/0304-405x(80)90019-7

Donaldson, G., \& Stone, N. D. (1984). Managing corporate wealth: The operation of a comprenhensive financial goals system. New York, NY: Praeger Publishers.

Drobetz, W., \& Fix, R. (2003). What are the determinants of the capital structure? Some evidence for Switzerland (Working paper no. 4/03). WWZ/ Department of Finance, University of Basel, Basel, Switzerland.

Ferri, C., E. F. \& Ehrhardt. (2005). Financial management: Theory and practice USA: department of accounting and finance (Unpublihsed master's thesis). University of Glasgow Brigham, Glasgow, Scotland.

Kamau, J. N. (2010). The relationship between capital structure and financial performance of insurance companies in Kenya (Unpublished master's thesis). University of Nairobi, Nairobi, Kenya.

Kuria, R. W. (2010). Determinants of capital structure of companies quoted in the NSE (Unpublihsed master's thesis). University of Nairobi, Kenya, Nairobi.

Kurniawan, F. I. (2018). Development of village owned enterprises (Bumdes) as a solution to achieve Mandiri Village. International Journal of Business and Economic Affairs, 3(5), 185-194. doi:https://doi.org/10.24088/ijbea-2018-35001

Modigliani, F., \& Miller, M. H. (1958). The cost of capital, corporation finance and the theory of investment. The American Economic Review, 48(3), 261-297.

Mugenda, O. M., \& Mugenda, A. G. (1999). Research methods: Quantitative and qualitative approaches. Kenya, Nairobi: Acts press.

Myers, S. C. (1984). Capital structure puzzle (Technical report). National Bureau of Economic Research, Cambridge, MA.

Odinga, G. O. (2003). Determinants of capital structure of small and medium-sized enterprises in Kenya (Unpublished master's thesis). University of Nairobi, Kenya, Nairobi.

Onegi, M., Eser, Z., \& Korkmaz, S. (2019). Consumers' evaluation of glocal marketing strategies of global firms in Turkey: An example of a glocal product. International Journal of Business and Administrative Studies, 5(3), 109-118. doi:https:// dx.doi.org/10.20469/ijbas.5.10001-3

Ozkan, A. (2001). Determinants of capital structure and adjustment to long run target: Evidence from UK company panel data. Journal of Business Finance \& Accounting, 28(1-2), 175-198. doi:https://doi.org/10.1111/1468-5957.00370 
Rajan, R. G., \& Zingales, L. (1995). What do we know about capital structure? Some evidence from international data. The Journal of Finance, 50(5), 1421-1460. doi:https://doi.org/10.1111/j.1540-6261.1995.tb05184.x

Saunders, M., Lewis, P., \& Thornhill, A. (2009). Research methods for business students. London, UK: Pearson education.

Shin, S. J., \& Seo, W. (2017). Identifying new technology areas based on firm's internal capabilities. Journal of Administrative and Business Studies, 3(3), 114-121. doi:https://doi.org/10.20474/jabs-3.3.1

Shyam-Sunder, L., \& Myers, S. C. (1999). Testing static tradeoff against pecking order models of capital structure. Journal of Financial Economics, 51(2), 219-244. doi:https://doi.org/10.3386/w4722

Titman, S., \& Wessels, R. (1988). The determinants of capital structure choice. The Journal of Finance, 43(1), 1-19. doi: https://doi.org/10.1111/j.1540-6261.1988.tb02585.x

Turere, S. P. (2012). The determinants of capital structure in the energy and petroleum companies listed in the Nairobi securities (Unpublished master's thesis). University of Nairobi, Kenya, Nairobi. 